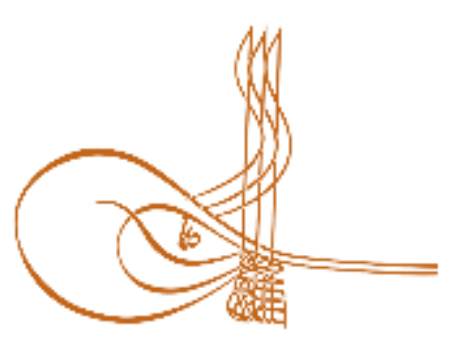

www.turkishstudies.net/turkishstudies
Turkish Studies

eISSN: $1308-2140$

Research Article / Araștırma Makalesi

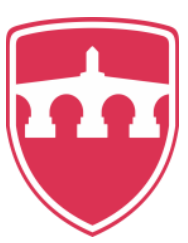

INTERNATIONAL

BALKAN

UNIVERSITY

Sponsored by IBU

\title{
Katılımlı Dinleme Türünün Ortaokul 5. Sınıf Öğrencilerinin Dinlediğini Anlama Becerisi Üzerindeki Etkisi*
}

\author{
Influence of Participative Listening Type on Listening Comprehension Skills of 5th Grade Students
}

\author{
Fatih Sevimli $^{* *}$ - Fulya Topçuoğlu Ünal ${ }^{* * *}$
}

\begin{abstract}
Participatory listening is conveying the questions or opinions about the subject to the speaker in the listening process and communicating with the person. Making the listeners and the questions listened to the person by communicating them to the speaker provides the speaker to relax and reach the purpose of the communication. Asking the speaker to clarify what he said and summarizing the ideas and feelings of the speaker are among the features of attentive listening. It is the basis of participative listening not to deal with any other work and establish eye contact with the speaker during listening. The aim of this research is identifying Influence of Participative listening on listening comprehension skills of 5th grade students consisting planned activities. Experimental design, which has pre testpost test controlled group, is used while collecting, analyzing and interpreting the data gathered by this way. The study has corried out with 40 students consists of experimental and control groups in 5-A 5-B classes of Middle School students in 20132014 Educational year located in city center. Listening comprehensive test is applied to the controlled group for pre-test and post-test. According to the pre test scores it is determined that listening skills of half experimental and control groups are similar. After the pre-test, participative listening training has given for ten weeks. The lesson of experimental group has given with the activities designed as part of participative listening. On the other hand the control group lessons are designed as part of Turkish lesson syllabus. Different types of activities are given in the research. In the conclusion of the study Wilcoxon signedranks test, mann-whitney $\mathrm{U}$ test frequency and percentage analyseare used on the data gathered quantitatively. Examining the data it is seen that; experimental points average are 29.30, controlled groups' average are 11.70. According to this conclusion, results are increased on behalf of the experimental groups. Participative listening has positive effect on the test group students' listening acquisition in Turkish syllabus.
\end{abstract}

\footnotetext{
* Bu çalışma 2015 yılında tamamlanan "Katılımlı Dinlemenin Ortaokul 5. Sınıf Öğrencilerinin Dinlediğini Anlama Becerisi Üzerindeki Etkisi” isimli yüksek lisans tezinden üretilmiştir.

** Türkçe Öğretmeni, Köprüören Tek Termik Ortaokulu

Turkish Teacher, Köprüören Tek Termik Middle School

ORCID 0000-0003-1229-6032

fatihsevimli85@hotmail.com

**** Doç. Dr., Dumlupınar Üniversitesi, Eğitim Fakültesi, Türkçe Eğitimi Bölümü

Assoc. Prof. Dr., Dumlupinar University, Faculty of Education, Department of Turkish Education

ORCID 0000-0003-3981-9841

fulya.topcuoglu.unal@dpu.edu.tr

Cite as/ Atıf: Sevimli, F., Topçuoğlu Ünal, F. (2020). Katılımlı dinleme türünün ortaokul 5. sınıf öğrencilerinin dinlediğini anlama becerisi üzerindeki etkisi, Turkish Studies, 15(2), 1269-1283. https://dx.doi.org/10.29228/TurkishStudies.40588

Received/Geliş: 16 January/Ocak 2020

Accepted/Kabul: 25 April/Nisan 2020

Copyright (C) MDE, Turkey

Checked by plagiarism software

Published/Yayın: 30 April/Nisan 2020

CC BY-NC 4.0
} 
Structured Abstract: Research was carried out to determine the Effect of Participatory Listening Type on the Understanding of Listening Students of Middle School 5th Grade.

\section{Method}

In the research, semi-experimental model with pretest-posttest control group, which is one of the experimental research models, was used.

\section{Working Group}

The study group consists of 40 students who study at 5th grade in a public secondary school in 2013-2014 academic year in Kütahya.

\section{Data Collection}

"Web Based Listening Comprehension Test" was applied as a pretest. The test results were analyzed by using the Mann Whitney U-test analysis to determine whether there was a significant difference between the mean scores of the two groups in the comprehension achievement test. The difference between the pretest and posttest scores of the experimental group and the difference between the pretest and posttest scores of the control group were analyzed with the Wilcoxon test.

\section{Research Findings and İnterpretation}

The results of Mann Whitney $U$ test related to the difference between the pretest scores of the experimental and control group students' listening comprehension achievement test are given. When the findings are analyzed, it is seen that the average scores of the students in the experimental group's listening comprehension achievement test are 20.58 in the mean score of the students in the control group of 20.58 . Accordingly, it is seen that there is no significant difference between the scores of the experimental and control groups on the listening comprehension achievement test. The results of Mann Whitney U test related to the difference between the posttest scores of the experimental and control group students' listening comprehension achievement test are given. When the findings are analyzed, it is seen that the average scores of the experimental group students' listening comprehension achievement test score is 29.70 and the average score of the students in the 29.30 control group is 11.70 . Accordingly, it is seen that there is a significant difference between the scores of the experimental and control groups in the comprehension achievement test. The results of the Wilcoxon Test regarding whether the listening comprehension test pretest and posttests applied to the students in the experimental group show a statistically significant difference shows that there is a statistically significant difference between the scores of the experimental group students before and after the application. Considering the rank average and totals of the difference scores, it is seen that this observed difference is in favor of positive ranks, that is, the posttest score. According to these results, it can be said that Participatory Listening has an important effect on the comprehension ability of 5th grade students listening. The results of Wilcoxon Test results regarding whether the listening comprehension test pretest and posttests applied to the students in the control group show a statistically significant difference shows that there is a statistically significant difference between the scores of the control group students before and after the application.

\section{Conclusion}

In order to improve the listening comprehension skill, it was determined that there was a significant difference between the experimental group, in which the listening activities were applied, by following the processes according to the Turkish curriculum, by looking at the results of the tests according to the control group where the lessons were taught and the same tests were applied. As a result of the findings obtained, it was seen that, in order to improve the listening skill, it contributes to improving the listening comprehension skill when the participatory listening activities suggested in achieving the objectives specified in the Turkish program are fully implemented. With this study, it was seen that listening skill could improve with activities appropriate to the level. The pretests of the experimental group and the control group students were compared in terms of their total scores, and there was no significant difference between the pretest total scores of the experimental group students. In this case, it was determined before the application that the experimental group and the control group students were similar in terms of listening skills. When the pre-test and post-test scores were compared in terms of the total scores of the experimental group students, the posttest scores were found to be significantly different from the pre-test scores. This result shows that listening with the given participations improves students' listening skills. When the total scores of the control group

Turkish Studies, 15(2) 
students from the pre-test and post-test were compared, it was seen that there was a significant difference between the pre-test and post-test results. The reasons for the post-test total scores of the students in the control group are higher than the pre-test total scores can be explained as follows: Each theme in elementary 5th grade Turkish lessons includes a listening text and listening activities for this text. The increase in students' scores may be a natural result of listening education in Turkish lessons. In addition, since the text and text questions used in the pre-test and post-test were the same, students remembered their experience in the pre-test during the post-test application; he may have listened to the text to find answers to the questions he remembered and to find important points. It may be thought that another reason for the increase in the students 'scores is due to the students' cognitive development during the 10 -week application period. The posttests of the experimental group and the control group students were compared in terms of their total scores, and the posttest total scores of the experimental group students were significantly higher than the posttest total scores of the control group students. In this case, it can be said that listening with the participant group students improves their listening skills. When all these results are evaluated, it was determined that the education given to the experimental group students improved the listening skills of the students. There is a significant difference between the group of education and the group that did not receive education in favor of the experimental group. It was demonstrated with this study that participatory listening could improve the listening skills of students.

Keywords: Listening, listening skill, listening types, participative listening, secondary school.

Öz: Katılımlı dinleme, dinleme sürecinde dinleyicide konu hakkında oluşan soru veya görüşlerin konuşmayı yapan kişiye iletilmesi ve o kişiyle iletişim kurulmasıdır. Dinlenilenlerin ve soruların konuşan kişiye iletilerek karşısındakine dinlediğini hissettirme, konuşmacının rahatlamasını ve iletişimin amacına ulaşmasını sağlar. Konuşan kişiden söylediklerine açıklık getirmesini istemek, konuşan kişinin belirttiği fikir ve duygularını özetlemek katılımlı dinlemenin özellikleri arasında yer alır. Dinleme esnasında başka bir işle uğraşmamak ve konuşmacı ile göz teması kurmak katılımlı dinlemenin temelidir. Bu araştırmanın amacı planlanmış etkinlikler içeren "Katılımlı Dinleme Yönteminin Ortaokul 5. Sınıf Öğrencilerinin Dinlediğini Anlama Becerisi Üzerindeki Etkisi”ni tespit etmektir. Bu doğrultuda elde edilen verilerin toplanması, analizi ve yorumlanmasında nicel araştırma yöntemlerinden ön test-son test kontrol gruplu yarı deneysel desen kullanılmıştır. Araştırma 2013-2014 eğitim-eğretim yılında Kütahya il merkezindeki bir devlet okulunda öğrenim görmekte olan 5-A ve 5-B sınıfı deney ve kontrol gruplarında bulunan toplam 405 . sınıf öğrencisi ile birlikte gerçekleştirilmiştir. Çalışma grubuna ön test ve son test olarak dinlediğini anlama testi uygulanmıştır. Deney ve kontrol grubunun dinleme becerilerinin ön test puanları açısından benzer olduğu tespit edilmiştir. Ön test sonrası 10 hafta süren katılımlı dinleme eğitimi çalışması düzenlenmiştir. Deney grubundaki dersler katılımlı dinleme türü kapsamında planlanmış etkinliklerle, kontrol grubunda ise Türkçe dersi öğretim programının gerektirdiği süreçler takip edilerek işlenmiştir. Araştırma için öğrencilere farklı türde dinleme metinleri ve bu metinlere yönelik etkinlikler düzenlenmiştir. Nicel olarak elde edilen veriler üzerinde Wilcoxon işaretli sıralar testi, Mann-Whithey U testi, frekans ve yüzde analizleri kullanılmıştır. Bulgular incelendiğinde deney grubu öğrencilerinin dinlediğini anlama başarı testinden almış oldukları puanların sıra ortalamasının 29.30 kontrol grubundaki öğrencilerin puanlarının sıra ortalamasının ise 11.70 olduğu görülmektedir. Bu sonuca göre öğrencilerin dinleme testi sonuçlarında deney grubu lehine istatistiksel olarak anlamlı bir farklılık tespit edilmiştir. Katılımlı dinleme deney grubu öğrencilerinin Türkçe öğretim programındaki dinleme kazanımlarını uygulama düzeyleri üzerinde olumlu etkiye sahiptir.

Anahtar Kelimeler: Dinleme, dinleme becerisi, dinleme türleri, katılımlı dinleme, ortaokul.

\section{Giriş}

İnsanların iletişim kurmalarını sağlayan en temel araç dildir. Dil aracılığıyla duygularımızı, düşüncelerimizi ve isteklerimizi ifade edebiliriz. Dil insanların birbirleriyle anlaşmalarının en önemli vasıtası olduğu için dilin etkili kullanılması ve dil eğitimine gereken önemin verilmesi gerekmektedir. Dil öğretiminin temelini dinleme, konuşma, okuma ve yazma becerileri oluşturmaktadır. Temel dil becerisi olarak adlandırılan okuma, yazma, dinleme ve konuşma becerilerini gerçekleştirme durumuna göre iletişim sağlıklı gerçekleşmektedir. Temel dil 
becerilerinin kazanılamaması durumunda iletişim ağında sıkıntı meydana gelecek ve anlamaanlatma eylemi tam gerçekleştirlememiş olacaktır.

Temel dil becerileri arasında, dinleme ve konuşma becerilerinin insan yaşamının en temel ve ayrılmaz iki becerisi olduğuna dair Topçuoğlu Ünal \& Özden (2012) bireyin hayatı boyunca okuma ya da yazma olmadan yaşamını devam ettirebileceğini, fakat konuşma ve dinleme becerilerini kullanmadan hayatına devam etmesinin zor olduğunu belirtmektedirler. Temel dil becerilerinin içinde dinlemenin ayrıca özel bir yeri vardır. Okuma, yazma ve konuşma dil becerileri dinleme yoluyla öğrenilmektedir (Doğan \& Erdem, 2018: 290). Dinleme daha anne karnındayken kullanılmaya başlanan dil becerisidir. Aynı zamanda insanların günlük hayatta en çok kullandıkları bir beceridir. Uluslararası Dinleme Derneğine (International Listening Association-ILA) göre dinleme; konuşandan gelenleri algılama, ondan anlam yapılandırma ve sözel ve/veya sözel olmayan mesajlara karşıllk verme sürecidir (ILA, 2014). Türkçe Sözlükte (TDK, 2005, s. 671) ise dinleme "İ̧sitmek için kulak vermek." şeklinde tanımlanmıştır. Dinleme, kişinin okul hayatında ve okul hayatından sonra edindiği iletişim becerisini dinediklerini doğru yorumlayabilmesi açısından doğru bir şekilde kullanmasını sağlayan önemli bir beceridir (Çiftçi, 2007) Dinleme becerisi gelişmiş bireyler, çevrelerindeki insanlarla sağlıklı bir iletişim kurabilen, eğitim-öğretim hayatında başarılı bireylerdir. Buna rağmen bu güne kadar yapılan dinleme becerisi alanındaki çalışmaların yetersiz kaldığ 1 görülmektedir. Dinleme, programların yetersizliği, yöntem ve tekniklerin bilinmemesi, bu becerinin ölçme ve değerlendirilmesinin zorluğu gibi sebeplerle eğitimde de çok ihmal edilmiş bir beceridir. "Günlük hayatta sürekli kullanılan dinleme becerisi geliştirilebilen bir beceridir. Doğduğumuz andan itibaren kullanılan tek dil becerisi olan dinleme becerisinin geliştirilmesi öncelikle ana dili öğretim merkezi olan aile ve yakın çevrede başlamaktadır. Daha sonra ise bireyin eğitim-öğretim hayatının başladığı okulla ve yaşantılarıyla devam etmektedir.”(Topçuğlu Ü̉nal \& Özer, 2014).

Dinleme günün her anında gerçekleştirilebilen bir beceridir. Sever (2011: 11) kişilerin diğer kişilerle birlikte olduğu sürenin \%42'sini dinleyerek geçirdiğinin çalışmalarla tespit edildiğini belirtmektedir. Bununla birlikte Hunsaker (1990. akt. Akyol, 2010: 1) bildiklerimizin neredeyse \%80'inin dinleme yoluyla edinildiğini ifade etmektedir. Ergin (2010: 107) Amerika'da yapilan çalışmalarda, bir ilköğretim öğrencisinin okuldaki zamanının \%50'sini dinleyerek geçirdiği ve bu oranın üniversitelerde \%90'lara ulaştığını belirtmektedir.

Dinlemeyi sadece eğitimde kullanılan bir beceri değildir. Hayatımızın hemen her alanında ihtiyaç duyduğumuz bir beceridir. Robertson (2004: 152) araştırmasında, müşterilerin kendilerini iyi dinleyecek bir çalışan bulamayınca o kurumdan alışveriş yapmayı $\% 68$ oranında kestikleri tespit etmiştir. Buna benzer bir şekilde Laster ve Smith (1993: 270) ise bir doktorun hastasını iyi dinlemesinin hastanın probleminin ne olduğunun teşhisinde çok önemli olduğu, hatta hastaların psikolojilerine bile iyi gelebildiğini belirtmektedirler (Ungan, 2009: 141).

Hayatın birçok alanında çokça kullanılan dinleme becerisi eğitim-öğretim hayatında da çok büyük bir öneme sahiptir. Dinleme becerisi gelişmiş öğrencilerin dersleri anlama düzeylerinin artacağı ve ders başarısının buna paralel olarak yükseleceği söylenebilir (Doğan, 2010).

Dinlemenin eğitim-öğretim sürecindeki önemine Türkçe öğretim programında da değinilmiştir. Programda dinlediklerini/izlediklerini sıralama, sınıflama, sorgulama, ilişkilendirme, eleştirme ve bunlarla ilgili çıkarımlarda bulunma gibi üst becerileri (MEB 2006, s.5) geliştirmeye yönelik ifadeler yer almaktadır. Öğrencilerin bu üst becerilere ulaşması için 42 kazanım yer almaktadır.

Dinleme gelişigüzel yapılarak geliştirilen bir beceri değildir. Dinleme, uygun yöntem ve tekniklerle gerçekleştirilmesi gereken bir dil becerisidir. Ayrıca dinlemenin kendi içinde birçok türü vardır. Dinlemenin türünü dinleme sırasında kullanılan yöntem belirler. $\mathrm{Bu}$ yöntemin belirlenmesi ise, dinleme amacına ve dinlenecek konunun özelliklerine bağlıdır. 
Dinleme türüyle ilgili alınyazında birçok sınıflandırma görülmektedir. Ayrıca bu sınıflandırmaların birbirinden bazı farklılıkları vardır. Burada Milli Eğitim Bakanlığı, Türkçe dersi öğretim programında yer alan dinleme türlerine yer verilecektir. Milli Eğitim Bakanlığı, Türkçe dersi öğretim programında dinleme/izleme yöntem ve teknikleri aşağıdaki gibidir (MEB, 2006, s. 62-63);

Katılımsız dinlemede öğrencilerin dinledikleri üzerinde düşünmelerini sağlanarak zihinsel faaliyetlerini harekete geçirmek amaçlanmaktadır. Kendini konuşanin yerine koyarak dinleme yani diğer adıyla empati kurmada adından da anlaşılacağ 1 gibi dinleyicinin kendisini konuşanın yerine koyması bu vesileyle konuşanın hislerini, duygu ve düşüncelerini, olayları algılama şeklini anlamak amaçlanmaktadır. Yaratıcı dinlemede dinleyicinin dinlediklerini yorumlaması ve dinlediklerinden yeni fikirler üretmesi amaçlanmaktadır. Seçici dinlemede dinlenilen konudan dinleyicinin kendi ilgisine ya da ihtiyacına yönelik konuların seçilerek dinlenmesi amaçlanmaktadır. Eleştirel dinlemede dinleyicilere dinledikleri konu üzerinden soru sorma alışkanlığı kazandırmak, dinledikleri konu üzerine düşünmeleri, tarafsız bir şekilde olumlu ve olumsuz yönleriyle konuyu değerlendirmeleri amaçlanmaktadır. Not alarak dinlemede konunun daha basit anlaşılması ve hatırlanmasını sağlamak amaçlanmaktadır.

Katılımlı dinlemede ise konunun daha iyi kavranması için dinleme esnasında zihinde oluşan soruların konuşan kişiye aktarılması amaçlanmaktadır. Konuşmacıya aktarılan sorular dinleyicinin konuyu daha iyi dinlediğini hissettirdiği için, konuşmacının gevşemesini ve iletişimin beklenen şekilde gerçekleşmesini sağlar. Dinleyici soru sorduğu ya da hissettiklerini paylaştığı için dinleyici de, dinleme sürecine aktif olarak katılmış olur. Katılımlı dinleyici dinleme esnasında pasif kalmadığ için kapalı anlamlar, anlaşılmayan konular ortaya çıkmakta ve giderilmektedir. Yani dinleme olayı gerçekleşirken dinleyici ne kadar aktif olursa o derece dinleme becerisi gerçekleşmiş olur. Yani karşı tarafı pasif bir şekilde dinlemek değil, iletişimin gereği olarak mesajı tam olarak alma ve yorumlama çabasıdır (Umagan, 2007: 149). Bu da karşımızdaki bireye kendini gerçekten dinlediğimizi hissettirmeye dayanan (Yalçın, 2006:132) katılımlı dinlemede mevcuttur. Çünkü kapalı kalan anlamların ne olduğunun bulunmasında konuşmacıya sorulan sorular önemli bir yer tutar. Bireyler duygyuve düşüncelerini bazen net ya da açık açık söylemeyi tercih etmezler. Bunun yerine bazı semboller kullanırlar. Bu sembollerin çözümünde katılımlı dinleme sorulara yer verdiği için önem arz etmektedir. (Arı, 2008).

Katılımlı dinleme sadece dinleyici açısından değil konuşmacı açısından da çok önemlidir. Çünkü konuşmacı dinleyicinin katılımıyla dinlenildiğini hissedip kendine olan güvenin artmasını sağlayacaktır. Aksi takdirde anlattıklarının sıktığı düşüncesiyle dinlenilmeme korkusuna kapılıp durumdan kötü etkilenecektir. Bu sebeple katılımlı dinleme hem konuşmacı hem de dinleyici açısından kendilerini geliştirmeleri, birbirlerini anlamaları ve iletişimi tam olarak gerçekleştirmeleri açısından büyük bir firsat olarak görülebilir. Bunu öğrenciler ve öğretmenler üzerinden düşündüğümüzde de durum aynıdır. Çünkü konuşmacı öğrenciyse, öğretmeninin kendini dinlediğini gören bir öğrenci, öğretmenin ona değer verdiğini, önemsendiğini düşünerek derse olan ilgisini ve kendine ait özgüvenini artıracaktır. Bu durum, öğrenci-öğretmen arasında sağlıklı mesaj akışı sağlayacak ve öğrencinin öğretmeniyle olan dinamik bağını güçlendirecektir. Bu bakımdan öğrencilere katılımlı dinleme eğitimi verilerek öğrencilerin daha etkili dinleme gerçekleştirebilecekleri düşünülmektedir. $\mathrm{Bu}$ nedenle dinlemenin bir türü olarak kabul edilen katılımlı dinlemenin ortaokul 5. Sınıf öğrencilerinin dinlediğini anlama becerisine etkisi araştırılmıştır.

\section{Yöntem}

\section{Araştırma Modeli}

Bu çalışma, katılımlı dinlemenin ortaokul 5. sınıf öğrencilerinin dinlediğini anlama becerisi üzerindeki etkisini araştıran yarı deneysel bir araştırmadır. "Değiş̧kenler arası ilişkilerin kesinlikle 
saptanabilmesi sonucu kuramların geliştirilebildiği, kontrollü ve ulaştığı sonuçların kesin olması nedeniyle en güvenilir araştırma olarak kabul edilen araştırmalar deneysel araştırmalardır." (Ural \& Kılıç, 2006: 19).

$\mathrm{Bu}$ araştırmada deneysel araştırma modellerinden ön test-son test kontrol gruplu yarı deneysel model kullanılmıştır. "Ön test- son test kontrol gruplu modelde, yansız atama yoluyla oluşturulmuş iki grup bulunur. Bunlardan biri deney, öteki kontrol grubu olarak kullanılır. Her iki grupta da deney öncesi ve deney sonrası ölçmeler yapılır." (Karasar, 2008, s. 97). Buna göre araştırma yansız atanmış "ön test-son test kontrol gruplu yarı deneysel desenine (modeline)" uygunluk göstermiştir.

Araştırma için ortaokul 5. sınıf öğrencilerinden oluşan iki farklı grup seçilmiştir. Yansız (random) atama yoluyla gruplardan birisi deney, diğeri kontrol grubu olarak atanmıştır. Öğrenciler deneysel işlemden önce ve sonra bağımlı değişkenlerle ilgili olarak ölçüme tabi tutulmuşlardır. Deney grubunda katılımlı dinleme ve tekniklerine göre planlanmış etkinliklerle ders işlenirken, kontrol grubunda Türkçe dersi öğretim programının gerektirdiği süreçler takip edilerek işlenmiştir.

\section{Çalışma Grubu}

Araştırmanın çalışma grubunu Kütahya ilinde 2013-2014 eğitim-öğretim yılında bir devlet ortaokulunda 5. sınıfta öğrenim gören 40 öğrenci oluşturmaktadır. 5 sınıfların ortaokulun başlangıç y1lı olması ve çalışma yapılacak okulda birbirine eş iki sınıf düzeyinin 5. sınıflarda bulunması sebebiyle çalışma grubunun belirlenmesinde amaçlı örnekleme yöntemi kullanılmıştır. Örneklem olarak 5. sınıf öğrencilerinin seçilmesi, öğrencilerin kendilerinin öğretmenler tarafından dinlenildiğini ve fikirlerine değer verildiği görmeleri açısından kişiliğin oturmaya başladığı bu gelişim dönemindeki çocuklar için önem arz etmektedir.

Araştırma öncesinde okuldaki Türkçe öğretmeniyle görüşülmüş, "Katılımlı Dinlemenin Ortaokul 5. Sınıf Öğrencilerinin Dinlediğini Anlama Becerilerine Etkisi” konulu bir araştırma yapılacağı belirtilmiş ve araştırma ve araştırmanın süreci hakkında ayrıntılı bilgiler verilmiştir. Alınan resmi izin doğrultusunda araştırmanın bu okulda yapılabileceği ve çalışmanın tüm ayrıntıları okul müdürü ile paylaşılarak karar verilmiştir.

Araştırmanın yapılacağı sınıflardaki öğrenciler belirlendikten sonra Milli Eğitim Bakanlığı e-okul sisteminde öğrencilerin anne ve babalarının eğitim durumları, gelir düzeyleri vb. unsurlar kontrol edilmiş ve uygulama yapılacak sınıfların öğrencilerinin de birbirine çok yakın, sosyoekonomik açıdan homojen bir yapıya sahip oldukları görülmüştür. Zaten öğrenciler taşımalı eğitim veren okulda eğitim gördükleri, sosyal ve kültürel olarak benzer yerleşim yerlerinden okula geldikleri için öğrencilerin durumları benzerlik göstermektedir. Bununla birlikte öğrencilere ilişkin betimsel veriler öğrencilere verilen "Kişisel Bilgi Formu"ndan da tekrar elde edilmiştir.

Buna göre rastlantısal olarak deney grubu olarak 5/A sınıfi öğrencileri, kontrol grubu olarak da 5/B sınıfı öğrencileribelirlenmiştir. Deney grubunda 5/A sınıfında öğrenim gören 20, kontrol grubunda da 5/B sinıfinda öğrenim gören 21 öğrenci yer almaktadır. Kontrol grubu öğrencilerinden biri kaynaştırma eğitimi alan öğrenci olduğu için çalışmaya katılamamıştır. Dolayısıyla deney grubu olarak belirlenen şubedeki 20 öğrenci ile kontrol grubu olarak belirlenen şubedeki 20 öğrenci olmak üzere toplamda 40 öğrenci çalışma grubunu oluşturmaktadır. Belirlenen bu iki sınıfın dinleme becerileri arasında farklılığın olup olmadığını belirlemek için ön test uygulanmıştır.

Araştırmaya katılan 5. sınıf öğrencilerinin cinsiyet özeliklerine ilişkin bilgiler aşağıdaki tabloda verilmiştir (Tablo1). 


\begin{tabular}{ccccc}
\hline \multicolumn{2}{c}{ Tablo 1: Araştırmaya Katılan Öğrencilerin Cinsiyet Özelliklerine İlişkin Bilgiler } \\
\hline \multirow{2}{*}{ Cinsiyet } & \multicolumn{2}{c}{ Deney Grubu } & \multicolumn{2}{c}{ Kontrol Grubu } \\
\hline & $\mathrm{N}$ & $\%$ & $\mathrm{~N}$ & $\%$ \\
\hline $\mathrm{K} 1 \mathrm{z}$ & 10 & 50,0 & 10 & 50,0 \\
\hline Erkek & 10 & 50,0 & 10 & 50,0 \\
\hline Toplam & 20 & 100,0 & 20 & 100,0
\end{tabular}

Tablo 1'de araştırmaya katılan öğrencilerin cinsiyet özelliklerine ilişkin bilgiler yer almaktadır. Tabloya göre deney grubundaki öğrencilerin 10'u kız, 10'u erkektir. Yüzde olarak ifade edildiğinde deney grubu öğrencilerinin \% 50'sinin k1z, \% 50'sinin erkek olduğu görülmektedir. Kontrol grubu öğrencilerinin de aynı șekilde 10’u kız, 10'u erkektir. Yüzde olarak ifade edildiğinde deney grubu ögrencilerinin \% 50'sinin kı, \% 50'sinin erkek olduğu görülmektedir. Buna göre deney ve kontrol grupları arasında cinsiyet ve sayı özellikleri bakımından bir fark yoktur.

\section{Verilerin Toplanması}

Öğrencilerin dinlediğini anlama başarılarının durumunu görebilmek için "Web Tabanlı Dinlediğini Anlama Testi” ön test olarak uygulanmıştır. Test sonuçlarına Mann Whitney U-testi analizi yapılarak iki grubun dinlediğini anlama başarı testinden aldıkları puan ortalamaları arasında anlamlı farklılık bulunup bulunmadığı değerlendirilmiştir. Normallikten çok uzak veri setinin olması durumunda iki bağımsız grupta farklı varyanslı iki ortalama arasındaki farkın aynı olup olmadığını test etmek için Mann Whitney U-testi kullanılır (Akgül \& Çevik, 2003). "Mann Whitney U-testi, iki ilişkisiz örneklemden elde edilen puanların birbirinden anlamlı bir şekilde farklıl1k gösterip göstermediğini test eder." (Büyüköztürk, 2012, s. 155).

Deney grubunun ön test ve son test puanları arasındaki fark ve kontrol grubunun ön test ve son test puanları arasındaki fark ise Wilcoxon testi ile analiz edilmiştir. "Wilcoxon işaretli sıralar testi ya da Wilcoxon eşleştirilmiş çiftler testi olarak bilinen bu teknik, ilişsili iki ölçüm setine ait puanlar arasındaki farkın anlamlılığını test etmek için kullanılır. Bu test ilişkili iki ölçüm setine ait fark puanlarının yönünün yanı sıra miktarlarını da dikkate alır." (Büyüköztürk, 2012, s. 162).Wilcoxon işaretli sıralar testi, veriler normalden çok uzak ve simetrik ise uygulanabilir. $\mathrm{Bu}$ test aynı zamanda parametrik bir test olan "Wilcoxon eşleştirilmiş çiftler testi" ne alternatif olarak uygulanan ve parametrik olmayan bir testtir (Akgül \& Çevik, 2003).

\section{Veri Toplama Araçları}

Öğrencilerin dışarıdan gelebilecek uyarıcılardan uzak ve rahat bir şekilde dinlediklerini anlamalarını sağlamak için "Web Tabanlı Dinlediğini Anlama Testi” tercih edilmiştir. Web Tabanlı Dinlediğini Anlama Testi; Kaya (2012) tarafından geliştirilerek, 5. sınıf öğrencilerinin dinlediğini anlama becerilerini web tabanlı bir sistem üzerinden ön test ve son test șeklinde uygulanarak gerçekleştirilmiştir. Geçerlik ve güvenirlik çalışmaları yapılan (Acat ve diğerleri, 2013) aracın kullanımı için yazardan gerekli izin alınmıştır. Testin Cronbach Alfa ve KR-20 güvenirlik kat sayısı eşit çıkmıştır. Cronbach Alfa .77; KR-20 güvenirlik kat sayısı .77 bulunmuştur. Bununla birlikte iki yarı yöntemiyle hesaplanan güvenirlik katsayısı Spearman-Brown düzeltmesinin ardından .80 olarak elde edilmiştir. Bu değerler testin güvenilir olduğunu göstermektedir. Testin kapsam geçerliliği için Türkçe Dersi Öğretim Programında yer alan dinleme/izleme becerisine ait kazanımları ölçmeye yönelik 41 madde bulunmaktadır. 
Web Tabanlı Dinlediğini Anlama Testinin kullanılma amacı, testin uygulanacağı öğrenci sayısının fazlalığına bakılmaksızın bütün öğrencilerin aynı şartlarda olmalarını sağlamasıdır. Ayrıca ölçümlerden gerçeğe en yakın sonuçlar elde edilebilmesi için web üzerinde öğrencilerin süreç içerisinde bireysel ve dış etkenlere kapalı olabilecek ve verdikleri cevapları değiştirmelerini engelleyebilecek bir sistem olması nedeniyle de bu test tercih edilmiştir. Bununla birlikte kendi kontrollerinde olduğu için öğrencilerin multimedya ve web tabanlı etkinlikleri zevk alarak yaptıkları ve daha fazla soruyu doğru cevapladıklarını çalışmalarla ortaya konmuştur (Jones, 2003; Weinberg, 2002). Aynı zamanda Weinberg (2002), internet tabanlı video ve ses birleşiminden meydana gelen ortamların öğretmen ve öğrencilerin dinleme becerilerini geliştirdiği sonucuna ulaşmıştır.

Uygulama, araştırmacının denetiminde gerçekleştirilmiştir. Öğrencilere ders saatlerinde bilgisayar temin edilmiş, her öğrenci tek bir bilgisayarı kullanacak şekilde yerleştirilmiştir. Testi diş etkilerden bağımsız bir şekilde gerçekleştirebilmeleri için kulaklık verilmiştir. Verilerin toplanabilmesi için bir web adresi üzerinde çevrimiçi ölçme sistemi geliştirilmiştir. Bu sistem sayfa sayfa hazırlanmış ve öğrencilerin sisteme giriş yapabilmeleri için her öğrenciye birer kod verilmiştir. Öğrenciler kendilerine verilen kodu ilgili alana girdikten sonra "Kişisel Bilgiler"in olduğu sayfa ile karşılaşmışlardır. Öğrencilerin gerekli alanları doldurmaları zorunlu tutulmuş, doldurmayanlar sistem tarafından uyarı ekranıyla karşılaşmışlardır. Sonra gelen her bir sayfada seslendirilmiş bir metin/cümle ve onlara ait sorular yer almaktadır. Ancak bu sayfalara gelindiğinde medya oynatıcıyla metinlerin kendiliğinden okunmaları sağlanmış; dinlenenleri durdurma, geri alma, ileri sarma işlemlerini engellemek için "oynat, duraklat, durdur" düğmeleri kaldırılmıştır. Böylece metinlerin bir kez dinlenmesi otomatik olarak sağlanmıştır.

\section{Araştırmanın Uygulanması}

Araştırmanın ön testin yapılması, eğitim verilmesi ve son testin yapılması şeklinde gerçekleştirilmiştir.

İlk Aşama: Araştırmanın birinci uygulama aşamasında, 5/A ve 5/B sınıfları öğrencilerinden ön test için seçilen web ortamlı metni dikkatle dinlemeleri istenmiş ve dinleme etkinliği tamamlandıktan sonra öğrencilere yine web ortamlı metinle ilgili sorular yöneltilmiştir. Ön test sonuçlarında, aralarında istatistikî anlamda anlamlı bir fark olmayan sınıflardan deney grbu olarak 5/A sınıfi, kontrol grubu olarak da 5/B sınıfı belirlenmiştir.

İkinci Aşama: Araştırmanın ikinci uygulama aşamasında eğitim çalışmalarına yer verilmiştir. Kontrol grubu için 2013-2014 eğitim-öğretim y1lında il genelinde kullanılan özel yayınevi ders ve çalışma kitapları ile dersler işlenmiştir. Deney grubuna uygulanacak eğitim çalışmaları için uzman görüşleri doğrultusunda 2013-2014 eğitim öğretim yılı MEB yayınları Türkçe ders ve çalışma kitapları kullanılmıştır. Bu kitaplar sadece deney grubu derslerinde kullanılmıştır. Kitaptaki dinleme metinlerinden ve etkinliklerden yararlanılmıştır. Hazırlanan etkinliklerde öğrencilere öyküleyici metin, bilgilendirici metin, gölge oyunu, şiir türlerinde metinler kullanılmıştır. Kullanılan metinler, uygulamadan önce araştırmacılar ve alan uzmanları tarafından incelenmiştir. Öğrenciler tarafından daha kolay anlaşılmasını sağlamak amacıyla metinlerde uzun cümleler kısaltılmış, anlaşılması güç ifadeleri değiştirilmiştir. $\mathrm{Bu}$ etkinlikler oluştutulurken parçadan bütüne, kolaydan zora doğru gidilmiştir. Ayrıca etkinliklerin birbirini bütünler bir biçimde olmasına dikkat edilmiştir.

Katılımlı dinleme yöntemi ile öğrencilerin dinleme becerilerini geliştirmek amacıyla deney grubu öğrencilerine 10 hafta boyunca haftada 2 ders saati olmak üzere toplam 20 saat eğitim verilmiştir. Bu eğitim sürecinde 10 haftaya 10 ayrı metin seçilmiştir. Her metinle ilgili ilk olarak ön hazırlık çalışması yapılarak sorular sorulmuş, öğrencilerin hazır bulunuşlukları sağlanmıştır. Sonra konuyla ilgili katılımlı dinleme yöntemlerini kullanarak çeşitli etkinlikler yaptırılmıştır. Bunun yanı 
sıra kontrol grubu öğrencilerine konuyla ilgili herhangi bir eğitim verilmeyip, bu gruptaki öğrenciler derslerine olağan akışında devam etmiştir.

Üçüncü Aşama: Verilen eğitimin ardından uygulamanın üçüncü aşamasında, son test uygulamasına geçilmiştir. Son testte her iki gruptan da web ortamlı metni dikkatle dinlemeleri istenmiş, dinleme etkinliğinin ardından soruları cevaplamaları istenmiştir. Öğrencilerin verdiği cevaplar, ön testte olduğu gibi, araştırmacı ve gözlemci tarafindan ön testte olduğu gibi cevap anahtarına göre değerlendirilmiştir.

\section{Verilerin Analizi}

Çalışmada, Web Tabanlı Dinlediğini Anlama Testi için hazırlanan cevap anahtarı doğrultusunda elde edilen veriler bir istatistik programı kullanılarak analiz edilmiştir. Deney ve kontrol grubunun ön testleri ve son test puanları arasındaki fark Mann Whitney U testi ile analiz edilmiştir. Deney grubunun ön test ve son test puanları arasındaki fark ve kontrol grubunun ön test ve son test puanları arasındaki fark ise Wilcoxon testi ile analiz edilmiştir. Birinci tip hata $\% 5$ düzeyinde sabit tutulmuştur $(\mathrm{p}<.05)$.

\section{Bulgular ve Yorum}

\section{Deney ve Kontrol Grubunda Bulunan Öğrencilerinin Dinlediğini Anlama Becerileri Ön Test Puanlarına İlişskin Bulgular}

Deney ve kontrol grubu öğrencilerinin uygulama öncesi dinlediğini anlama becerileri açısından gruplar arasında anlamlı bir farkın olup olmadığını saptamak amacıyla Mann Whitney U testi yapılmıştır. Bu testin sonuçlarına ilişkin bulgular Tablo 2'de yer almaktadir.

Tablo 2: Dinlediğini Anlama Testinden Deney ve Kontrol Grubunun Aldıkları Ön Test Puanları Arasındaki Farka İlişkin Mann Whitney U Testi Sonuçları

\begin{tabular}{cccccc}
\hline Grup & $\mathrm{n}$ & Sira Ortalaması & Sira Toplamı & $\mathrm{U}$ & $\mathrm{p}$ \\
\hline Deney & 20 & 20.58 & 411.50 & 198.500 & .967 \\
\hline Kontrol & 20 & 20.43 & 408.50 & & \\
\hline
\end{tabular}

Tablo 2'de deney ve kontrol grubu öğrencilerinin dinlediğini anlama başarı testinden aldıkları ön test puanları arasındaki farka ilişkin Mann Whitney U testi sonuçları verilmiştir. Bulgular incelendiğinde deney grubu öğrencilerinin dinlediğini anlama başarı testinden almış oldukları puanların sıra ortalamasının 20.58 kontrol grubundaki öğrencilerin puanlarının sıra ortalamasının ise 20.43 olduğu görülmektedir. Buna göre deney ve kontrol gruplarının dinlediğini anlama başarı testinden aldıkları puanlar arasında anlamlı bir fark olmadığı görülmektedir $(\mathrm{U}=198.500, \mathrm{p}>.05)$.

\section{Deney ve Kontrol Grubunda Bulunan Öğrencilerinin Dinlediğini Anlama Becerileri Son Test Puanlarına İlişkin Bulgular}

Deney ve kontrol grubu öğrencilerinin uygulama sonrası dinlediğini anlama becerileri açısından gruplar arasında anlamlı bir farkın olup olmadığını saptamak amacıyla Mann Whitney U testi yapılmıştır. Bu testin sonuçlarına ilişkin bulgular Tablo 3 'te yer almaktadır. 
Tablo 3: Deney ve Kontrol Grubunun Dinlediğini Anlama Testinden Aldıkları Son Test Puanları Arasındaki Farka İlişkin Mann Whitney U Testi Sonuçları

\begin{tabular}{cccccc} 
Grup & $\mathrm{n}$ & Sira Ortalaması & Sira Toplamı & $\mathrm{U}$ & $\mathrm{p}$ \\
\hline Deney & 20 & 29.30 & 586.00 & 24.00 & .000 \\
\hline Kontrol & 20 & 11.70 & 234.00 & & \\
\hline
\end{tabular}

Tablo 3'te deney ve kontrol grubu öğrencilerinin dinlediğini anlama başarı testinden aldıkları son test puanları arasındaki farka ilişkin Mann Whitney U testi sonuçları verilmiştir. Bulgular incelendiğinde deney grubu öğrencilerinin dinlediğini anlama başarı testinden almış oldukları puanların sıra ortalamasının 29.30 kontrol grubundaki öğrencilerin puanlarının sıra ortalamasının ise 11.70 olduğu görülmektedir. Buna göre deney ve kontrol gruplarının dinlediğini anlama başarı testinden aldıkları puanlar arasında anlamlı bir fark olduğu görülmektedir $(U=24.00$, $\mathrm{p}<.05)$.

Deney Grubunda Bulunan Öğrencilerinin Dinlediğini Anlama Becerileri Ön Test ve Son Testten Aldıkları Puanlara İlişkin Bulgular

Deney grubunun ön testten aldıkları puanlar ile son testten aldıkları puanlar arasındaki farkın olup olmadığını saptamak amacıyla Wilcoxon Testi uygulanmıştır. Bu testin sonuçlarına ilişkin bulgular Tablo 4'te yer almaktadır.

Tablo 4: Deney Grubunun Ön Testten Aldıkları Puanlar ile Son Testten Aldıkları Puanlar Arasındaki Farka İlişkin Wilcoxon Testi Sonuçları

\begin{tabular}{|c|c|c|c|c|c|}
\hline Son test-Ön test & $\mathrm{n}$ & Sira Ortalaması & Sira Toplamı & $\mathrm{z}$ & $\mathrm{p}$ \\
\hline Negatif Sira & 0 & .00 & .00 & \multirow{3}{*}{$3.92^{*}$} & \multirow{3}{*}{.000} \\
\hline Pozitif Sira & 20 & 10.50 & 210.00 & & \\
\hline Eşit & 0 & - & - & & \\
\hline
\end{tabular}

*Negatif siralar temeline dayalı

Katılımlı dinlemenin ortaokul 5.sınıf öğrencilerinin dinlediğini anlama üzerindeki etkisini araştırmak için deney grubundaki öğrencilere uygulanan dinlediğini anlama testi ön test ve son testlerinin istatistiksel olarak anlamlı bir farklılık gösterip göstermediğine ilişkin Wilcoxon Testi sonuçları Tablo 4'te verilmiştir. Analiz sonuçları, deney grubu öğrencilerinin uygulama öncesi ve sonrasında aldıkları puanlar arasında istatistiksel olarak anlamlı bir fark olduğunu göstermektedir $(\mathrm{z}=3.92, \mathrm{p}<.05)$. Fark puanlarının sıra ortalaması ve toplamları dikkate alındığında, gözlenen bu farkın pozitif sıralar, yani son test puanı lehinde olduğu görülmektedir. Bu sonuçlara göre Katılımlı Dinlemenin Ortaokul 5. Sınıf Öğrencilerinin Dinlediğini Anlama Becerisi Üzerinde önemli bir etkiye sahip olduğu söylenebilir.

Kontrol Grubunda Bulunan Öğrencilerinin Dinlediğini Anlama Becerileri Ön Test ve Son Testten Aldıkları Puanlara İlişkin Bulgular

Kontrol grubunun ön testten aldıkları puanlar ile son testten aldıkları puanlar arasındaki farkın olup olmadığını saptamak amacıyla Wilcoxon Testi uygulanmıştır. Bu testin sonuçlarına ilişkin bulgular Tablo 5'de yer almaktadır. 
Tablo 5: Kontrol Grubunun Ön Testten Aldıkları Puanlar ile Son Testten Aldıkları Puanlar Arasındaki Farka İlişkin Wilcoxon Testi Sonuçları

\begin{tabular}{llllll}
\hline Son test-Ön test & $\mathrm{n}$ & $\begin{array}{l}\text { Sira } \\
\text { Ortalamas }\end{array}$ & Sıra Toplamı & $\mathrm{z}$ & $\mathrm{p}$ \\
\hline Negatif Sıra & 0 & .00 & .00 & \multirow{2}{*}{$3.92^{*}$} & \multirow{2}{*}{000} \\
\hline Pozitif Sıra & 20 & 10.50 & 210.00 & & \\
\hline Eșit & 0 & - & - &
\end{tabular}

*Negatif sıralar temeline dayalı

Katılımlı dinlemenin ortaokul 5.sını öğrencilerinin dinlediğini anlama üzerindeki etkisini araştırmak için kontrol grubundaki öğrencilere uygulanan dinlediğini anlama testi ön test ve son testlerinin istatistiksel olarak anlamlı bir farkl1lık gösterip göstermediğine ilişkin Wilcoxon Testi sonuçları Tablo 5'de verilmiştir. Analiz sonuçları, kontrol grubu öğrencilerinin uygulama öncesi ve sonrasında aldıkları puanlar arasında istatistiksel olarak anlamlı bir fark olduğunu göstermektedir $(\mathrm{z}=3.92, \mathrm{p}<.05)$.

\section{Tartışma ve Sonuç}

Araştırmada, katılımlı dinleme türünün ortaokul düzeyinde öğrenim gören 5. sınıf öğrencilerinin dinlediğini anlama becerisine etkisini belirlemek amaçlanmıştır. Amaca yönelik deney grubuna 10 haftalık uygulama çalışması yapılmıştır. Bu amaçla yapılan çalışmada deney ve kontrol grubunun ön test-son test sonuçları incelendiğinde anlamlı bir farklılığın ortaya çıktığı gözlenmektedir.

Yapılan çalışma süreci göstermektedir ki katılımlı dinleme sayesinde öğrencilerin konuyu anlayıp anlayamadığını, verdikleri geribildirimler ile kavram yanılgısına düşülen yerler kolaylıkla tespit edilmiştir. Araştırma sürecinde, katılımlı dinleme sayesinde öğrencilerin öğrenmiş oldukları konuları kendi cümleleriyle ifade etmeleri hem kendi özgüvenlerine olumlu yönde etki etkilediği gibi hem de anlatılan konudaki başarı düzeylerine de pozitif yönde bir katkı sağlamıştır.

Gordon'un (2004) katılımlı dinlemenin, öğrenmeyi kolaylaştırmada, araştırma, sorgulama, düşünme, tartışma, soru sorma ve kendilerini özgür hissedecekleri ortamı yaratmada güçlü bir araç olduğu ifadesi araştırmamızdaki bulgularla paralellik göstermektedir. Katılımlı dinleme ülkemizde uygulanan yapılandırmacı yaklaşımla da eşgüdümlü olarak kullanılabilmektedir. Bu sayede öğrencilerin anlamlı öğrenmelerinin önü açılmış olunacaktır.

Cihangir'in (2000) çalışmasında; etkin dinleme becerilerini geliştirmeye yönelik hazırlanan eğitim programının, üniversite birinci sınıf öğrencilerinin başkalarını dinleme becerileri üzerindeki etkisi incelenmiştir. Araştırma sonucunda üniversite öğrencilerinin başkalarını dinleme becerileri üzerinde etkin dinleme becerisini geliştirmeye yönelik yapılan eğitim programının etkisinin olumlu olduğu ve bu etkinin verilen eğitimden sonra da devam ettiği belirlenmiştir. Araştırma gruplarımız her ne kadar farklı olsada sonuçlar bakımından benzerlik göstermektedir. Bu durum katılımlı diğer bir ifadeyle etkin dinlemenin dinlediğini anlama üzerinde etkili olduğunu ortaya koymaktadır. Yine 6. Sınıf öğrencileri üzerinde benzer bir çalışma yapan Aytan (2011) deney grubuna verilen aktif öğrenme tekniklerine dayalı eğitimin kontrol grubunda yer alan öğrencilere göre dinleme becerilerini daha fazla geliştirdiğini tespit etmiştir.

Araştırma gruplarının aynı sınıf seviyesinden öğrenciler olmasıyla çalışmamıza benzerlik gösteren Koç'un (2003) dinleme becerilerini kazandırma yöntemlerinin uygulanması çalışmasında, dinleme becerilerini kazandırma yöntemleri ilköğretim 5. Sınıf öğrencilerine uygulanmıştır. Araştırma sonunda deney grubu öğrencilerinde uygulanan dinleme becerilerini kazandırma yöntemleri, kontrol grubu öğrencilerine göre daha başarılı olmuştur. Bu uygulamada kullanılan 
yöntemlerden "dramatizasyon" ise en başarılısı olmuştur. Farklı dinleme yöntemi olan dramatizasyonun da katılımlı dinlemenin bir parçası olduğu unutulmamalıdır.

Fidan (2012) araştırmasında ilköğretim ikinci kademe öğrencilerinin Türkçe derslerinde kullandıkları dinleme stratejilerini değerlendirmiş ve ilköğretim ikinci kademe öğrencilerinin kullandıkları dinleme stratejileri, öğrencilerin genel olarak bilişsel stratejilerden dikkat etme, not alarak dinleme, dinledikleri arasında ilişki kurma, tahminde bulunma, eleştirel dinleme, benzetim ve tekrar olarak belirlenmiştir. Zaten çalışmamızda da deney grubuna katılımlı dinleme uygulama çalışmaları sırasında öğrencilerin dinleme eylemine katılımlarıyla çok çeşitli etkinlikler yaptırılmıştır. Etkinliklerde öğrencinin aktif olması ve farklı etkinlik uygulamalarının dinlediğini anlamaya katkı sağladığı görülmüştür. Benzer yöntemleri kullanarak araştırma yapan Kaplan (2003) 6. sınıf öğrencilerinin dinleme becerileri üzerine bir araştırma yapmıştır. Dinlediğini anlama becerisinin geliştirilebileceği düşüncesinden yola çıkılarak araştırma sonunda; dinlediğini anlama becerisinin geliştirilmesi için yapılan çeşitli dinleme etkinliklerinin öğrencilerin dinleme becerilerini anlamlı derecede geliştirdiği, düzenli olarak okunan farklı türdeki metinlerin öğrencilerin ilk defa dinledikleri bir metni anlama seviyelerini yükselttiği sonucuna varılmıştır. Etkinliklerin dinleme metinlerini zevkli hale getirdiği ve dinleme becerisini geliştirdiği görülmüştür. Yapılan diğer araştırmalarda da (Karabay, 2005; İşeri ve Yılmaz, 2009) dinlemeye yönelik olarak yapılan etkinliklerin öğrencilerin dinleme becerilerini olumlu yönde etkilediği görülmektedir.

Dinleme türleri arasında yer alan "Not Alarak Dinleme" konusunda çalışma yapan Kocaadam (2011) çalışmasında, not alarak dinleme tekniği aracılığıyla ilköğretim 7. sınıf öğrencilerinin dinleme becerilerini geliştirmeyi amaçlamıştır. Deney grubu öğrecilerine not alarak dinleme eğitimi verilmiştir. Kontrol grubundaki öğrencilerle ise dersler olağan akışında devam etmiştir. Uygulama sonrasında deney ve kontrol gruplarınaa son test uygulanmıştır. Araştırmanın sonuçlarına göre, ilköğretim 7. Sınıf öğrencilerine verilen not alarak dinleme eğitiminin öğrencilerin dinleme becerilerini geliştirdiği bulgulanmıştır. Bu çalışma araştırmamız ile benzer özellikler göstermesi bakımından önem arz etmektedir. Her iki çalışmada dinleme türleri eğitiminin dinlediğini anlamaya etkisi tezi kanıtlanmış ve bulgular sonucunda dinleme türlerinin kullanılmasıyla yapılan dinleme faaliyetinin dinlediğini anlama becerisine önemli derecede katkısı bulunmuştur. Her iki çalışma, konusunun dinleme türü olması bakımından benzerlik; ancak aynı sınıf düzeyi olmaması bakımından farklılık göstermektedir.

Katılımlı dinleme becerisi kazandırmak için etkinliklerde tamamen öğrenci aktif hâle getirilmiştir. Ders işleme sürecinde gerek dinleme metinlerinin okunması esnasında gerekse etkinlikler yapılırken katılımlı dinlemenin gerektirdiği öğrenci merkezli anlayış ön planda tutulmuştur. Bu konuda İşeri \& Yılmaz (2009) dinleme becerisinin kazandırılması amaciyla yaptıkları çalışmalarında öğrencileri sürece katan etkinlikler gerçekleştirmişlerdir. Böylelikle ögrencilerin etkili dinleme becerisinin geliştiği ve başarılı oldukları sonucunu ortaya çıkarmışlardır. Araştırmamızın bulguları bu durumu doğrulamaktadır.

Soru cevap metodu deney grubunun eğitim çalışmalarının neredeyse her haftasında uygulanmış ve bu yolla dinlediğini anlama becerisinin arttığ 1 fark edilmiştir. Nuhoğlu, Başoğlu \& Kayganacıoğlu $(2006,187)$ Türkçe dersinde soru-cevap yönteminin sadece değerlendirme açısından değil aynı zamanda ders işleyiş açısından da önemli olduğunu belirtmektedirler. Bununla birlikte Kavcar ve diğerleri (1997) de soru-cevap tekniğinin görgü kurallarına uygun dinleme, konuşma ve tartışma becerilerini geliştireceğini belirtir. Çiftçi (2001) çalışmasında aktif dinleme açısından, tartışma, soru-cevap, gösterip yaptırma yöntem ve tekniklerinin daha uygun olduğunu belirtmiştir. Dinlemeyi etkileyen faktörlerden birinin de öğretmenin bu yöntem ve teknikleri uygulamadaki becerisi olduğunu belirtmiştir.

Öğretmen merkezli eğitimi dikkate alan, ezberciliği önemseyen ve öğrencileri pasif halde bırakan esasici eğitim anlayışı yerine öğrenciyi merkeze alan yapılandırmacı eğitim anlayışı 2005 
y1lından itibaren kullanılmaya başlanmış ve ülkemizin eğitim kalitesine önemli bir ivme kazandırmıştır. Bundan dolayı mevcut eğitim modelinin uygulanmasında katılımlı dinlemenin önemi artmaya devam etmektedir. Yapılan çalışma ile literatürdeki önemli bir boşluğun doldurulacağı öngörülmektedir.

İncelemeler sonunda elde edilen bulgulara ve yorumlara göre sonuçlar aşağıda belirtilmiştir. Dinlediğini anlama becerisini geliştirmek amacıyla katılımlı dinleme etkinliklerinin uygulandığı deney grubunun, Türkçe dersi öğretim programına göre süreçler takip edilerek derslerin işlendiği ve aynı testlerin uygulandığı kontrol grubuna göre testlerin sonuçlarına bakılarak aralarında anlamlı bir farklılık oluștuğu saptanmıștır. Elde edilen bulgular sonucunda dinleme becerisini geliștirmek için Türkçe programında belirtilen amaçlara ulaşmada önerilen katılımlı dinleme etkinlikleri tam olarak uygulandığında dinlediğini anlama becerisini geliştirmeye katk1 sağladığı görülmüştür. Bu çalışmayla dinleme becerisinin düzeye uygun etkinliklerle gelişebileceği görülmüştür.

Deney grubu öğrencileri ve kontrol grubu öğrencilerinin ön testleri toplam puanları açısından karşılaştırılmış, deney grubu öğrencilerinin ön test toplam puanları kontrol grubu öğrencilerinin ön test toplam puanları arasında anlamlı bir farklılığın olmadığı görülmüsstür. $\mathrm{Bu}$ durumda, uygulama öncesinde deney grubu öğrencileri ile kontrol grubu öğrencilerinin dinleme becerisi bakımından benzer olduğu belirlenmiştir.

Deney grubu öğrencilerinin toplam puanları açısından ön test ve son test puanları karşılaştırıldığında, son test puanlarının ön test puanlarından anlamlı derecede farklı olduğu görülmüştür. Bu sonuç, verilen katılımlı dinlemenin öğrencilerin dinleme becerisini geliştirdiğini göstermektedir.

Kontrol grubu öğrencilerinin ön test ve son testten aldıkları toplam puanlar karşılaştırıldığında, ön test ve son test sonuçları arasında anlamlı bir fark olduğu görülmüştür. Kontrol grubundaki öğrencilerin son test toplam puanlarının ön test toplam puanlarından yüksek olmasının sebepleri şöyle açıklanabilir: İlköğretim 5. Sınıf Türkçe derslerinde ele alınan her temada bir dinleme metni ve bu metne yönelik dinleme etkinlikleri yer almaktadır. Öğrencilerin puanlarındaki artış, Türkçe derslerindeki dinleme eğitiminin doğal bir sonucu olabilir. Ayrıca ön test ve son testte kullanılan metin ve metne yönelik sorular aynı olduğundan, öğrenciler, son testin uygulanması esnasında ön testteki deneyimini hatırlamış; metni, hatırladığı soruların cevaplarını ve önemli noktaları bulmaya yönelik dinlemiş olabilir. Öğrencilerin puanları arasındaki artışın bir diğer sebebinin de 10 haftalık uygulama sürecinde öğrencilerin bilişsel anlamda gelişme göstermelerinden kaynaklandığ 1 düşünülebilir.

Deney grubu öğrencileri ve kontrol grubu öğrencilerinin son testleri toplam puanları açısından karşılaştırılmış, deney grubu öğrencilerinin son test toplam puanları kontrol grubu öğrencilerinin son test toplam puanlarından anlamlı derecede yüksek çıkmıştır. Bu durumda, deney grubu öğrencilerine verilen katılımlı dinlemenin öğrencilerin dinleme becerilerini geliştirdiği söylenebilir.

Tüm bu sonuçlar değerlendirildiğinde deney grubu öğrencilerine verilen eğitimin öğrencilerin dinleme becerilerini geliştirdiği tespit edilmiştir. Eğitimin verilen grup ile eğitim verilmeyen grup arasında deney grubu lehine anlamlı bir farklılık görülmektedir. Katılımlı dinlemenin öğrencilerin dinleme becerilerini geliştirilebileceği bu çalışmayla ortaya konmuştur. 


\section{Kaynakça}

Acat, M. Demiral, H. \& Kaya M. F. (2013). Web tabanlı dinlediğini anlama testinin güvenirlik ve geçerlik çalışması. Pegem Ĕ̈itim ve Öğretim Dergisi, 3(3), 01-10. https://doi.org/10.14527/c3s3m1

Akgül, A. \& Çevik, O. (2003). İstatiksel analiz teknikleri. Emek Ofset.

Akyol, H. (2010). Yeni programa uygun Türkçe öğretim yöntemleri. Pegem Akademi Yayınc1lı. https://doi.org/10.14527/9786053640011

Arı, G. (2008). Dinleme/izleme öğretimi. C. Yıldız (Ed.) Kuramdan uygulamaya Türkçe öğretimi (s.179-202). Pegem Yayınlar1. https://doi.org/10.31464/jlere.549281

Aytan, T. (2011). Aktif öğrenme tekniklerinin dinleme becerisi üzerindeki etkileri, ODÜ Sosyal Bilimler Araştırmaları Dergisi (ODÜSOBIAD), 2 (4), 23-43.

Büyüköztürk, Ş. (2012). Sosyal bilimler için veri analizi el kitabı. 2. Baskı. Pegem Akademi Yayınc1lı. https://doi.org/10.14527/9789756802748

Cihangir, Z. (2000). Üniversite Öğrencilerine Verilen Etkin Dinleme Becerisi Eğitiminin Başkalarını Dinleme Becerisine Etkisi. Yayımlanmamış yüksek lisans tezi, Ankara Üniversitesi, Sosyal Bilimler Enstitüsü, Ankara.

Çiftçi, M. (2001). Dinleme eğitimi ve dinlemeyi etkileyen faktörler. Afyon Kocatepe Üniversitesi Sosyal Bilimler Dergisi, 2 (2), 165-177. https://doi.org/10.32709/akusosbil.484300

Çiftçi, Ö. (2007). Aktif dinleme, Millî Ĕgitim Dergisi, 176, 231-242.

Doğan, Y. (2010). Dinleme becerisi geliştirmede etkinliklerden yararlanma. Türklük Bilimi Araştırmaları Dergisi, (27), 263-274.

Doğan, B. \& Erdem, İ. (2018). Strateji temelli dinleme etkinliklerinin yedinci sınıf öğrencilerinin dinleme becerisiyle strateji kullanma düzeyine etkisi. International Journal of Language Academy, 6 (1), 289-315 https://doi.org/10.18033/ijla.3893

Ergin, A. (2010). Eğitimde etkili iletişim. Anı Yayınc1lık.

Fidan, M. (2012). İlköğretim ikinci kademe öğrencilerinin Türkçe dersinde kullandıkları dinleme stratejilerinin değerlendirilmesi. Yayımlanmamış yüksek lisans tezi, Erciyes Üniversitesi Eğitim Bilimleri Enstitüsü, Kayseri. https://doi.org/10.29000/rumelide.580463

Gordon, T. (2004). Etkili öğretmenlik ĕgitimi. Sistem Yayıncılık.

ILA. (2014, 22 May1s) International Listening Association. http://www.listen.org/

İşeri, K. \& Yılmaz, İ. (2009). Dinleme edimine ilişkin etkinliklerin değerlendirilmesi. Dil Dergisi TÖMER Yayinlarl, 139, 7-24.

Jones, L.(2003). Supporting listening comprehension and vocabulary acquisition with multimedia annotations: The students' voice. CALICO Journal, 21(1), 41-65. https://calico.org/p-5Calico\%20Journal.html (Erişim: 05.06.2012). https://doi.org/10.1558/cj.v21i1.41-65

Kaplan, H. (2003). İlköğretim 6. Sınıf Öğrencilerinin Dinleme Becerileri Üzerine Bir Araştırma. Yayımlanmamış Yüksek Lisans Tezi, Gazi Üniversitesi Eğitim Bilimleri Enstitüsü.

Karabay, A. (2005). Kubaşık öğrenme etkinliklerinin ilköğretim beşinci sınıf Türkçe dersinde öğrencilerin dinleme ve konuşma becerileri üzerindeki etkileri. Yayımlanmamış Yüksek Lisans Tezi, Çukurova Üniversitesi Sosyal Bilimler Enstitüsü, Adana https://doi.org/10.19129/sbad.303 
Karasar, N. (2008). Bilimsel araştırma yöntemi. Nobel Yayınları.

Kavcar, C., Oğuzkan, F. \& Sever, S. (1997). Türkçe öğretimi. Engin Yayınevi.

Kaya, M. F. (2012). İlköğretim 5. sınıf öğrencilerinin dinleme becerilerinin web tabanlı bir sistem yardımıyla ölçülmesi. Yayınlanmamış Yüksek Lisans Tezi, Eskişehir Osmangazi Üniversitesi, Eskişehir.

Kocaadam, D. (2011). Not alarak dinleme eğitiminin ilköğretim 7. sınıf öğrencilerinin dinleme becerisi üzerindeki etkisi. Yayımlanmamış Yüksek Lisans Tezi, Gazi Üniversitesi, Eğitim Bilimleri Enstitüsü, Türkçe Eğitimi Anabilim Dalı, Ankara. https://doi.org/10.1501/egifak_0000001359

Koç, N. (2003). Dinleme becerilerini kazandırma yöntemlerinin uygulanması. Yayımlanmamış yüksek lisans tezi, Çanakkale Onsekiz Mart Üniversitesi Sosyal Bilimler Enstitüsü, Çanakkale. https://doi.org/10.31454/usb.565480

MEB. (2006). İlköğretim Türkçe dersi (6, 7, 8. sınıflar) öğretim programı. MEB Yayınları.

Nuhoğlu M. M., Başoğlu N. \& Kayganacioğlu S. (2006). Türkçe öğretiminde ölçme ve değerlendirme. Nobel Yayıncılık. https://doi.org/10.14527/9786052419618.11

Sever, S. (2011). Türkçe ögrretimi ve tam öğrenme. Anı Yayınc1lık.

Topçuoğlu Ünal, F. \& Özer, F. (2014). Türkçe öğretiminde dinleme becerisi ile ilgili kaynakça çalışması. Journal of Research in Education and Teaching, 3 (2), 203- 218. https://doi.org/10.17719/jisr.2016.1413

Topçuoğlu Ünal, F. \& Özden M. (2012). Diksiyon ve konuşma eğitimi, Pegem Akademi. https://doi.org/10.14527/9786053642725

Ungan, S. (2009). Dinleme. A. Kırkkılıç ve H. Akyol (Ed.) İlköğretimde Türkçe ögrretimi (s. 135161). Pegem Yayınları.

Umagan, S. (2007), İlköğretimde Türkçe öğretimi, dinleme eğitimi (ss.149-163). Pegem A Yayınc1lik.

Ural, A. \& Kılıç, İ. (2006). Bilimsel araştırma süreci ve SPSS ile veri analizi. Detay Yayıncılık. https://doi.org/10.14527/9786053644484

Weinberg, A.(2002).Virtual Misadventures: Technical problem and student satisfaction when İmplementing multimedia in an advanced French listening comprehension course. CALICO Journal,19 (2),331-357. https://calico.org/p-5-Calico\%20Journal.html (Erişim:05.06.2012). https://doi.org/10.1558/cj.v19i2.331-357

Yalçın, A. (2006). Türkçe ögretim yöntemleri. Akçağ Yayınları. 